\title{
South Sudan Vehicle Workshop Hazardous Waste
}

\section{Management}

\author{
Zoran Chachorovski, Drasko Atanasoski, Micho Apostolov and Aneta Stojanovska-Stefanova \\ Faculty of Tourism and Business Logistics, University Goce Delcev, Shtip 2000, Republic of Macedonia
}

\begin{abstract}
All facility managers and fleet managers know how difficult it can be to effectively manage hazardous wastes and identify economic recycling opportunities. This report reviews the context surrounding GO's (global organization) vehicle workshops and environmental management in South Sudan, specifically relating to hazardous waste management. Potential recycling opportunities are identified and some preliminary suggestions for hazardous waste management are made.
\end{abstract}

Key words: Environment, legislation, policy, management, government, private sector.

\section{Introduction}

The environmental sustainability (facilities management) office and global fleet have teamed up to help find ways to save money and keep the environment clean with good management of hazardous wastes from vehicle maintenance workshops. Hazardous waste includes batteries, tyres, coolant, degreaser, waste oil, paints and thinners, refrigerants, waste chemicals, used oil filters and solvents. As I am a part of the team who is managing workshops around the country, I have visited some of the maintenance workshops to discuss with site workshop managers the challenges, find case studies of best practice and help to identify any possible new recycling/reuse/repurposing and waste elimination opportunities. Some examples of possible hazardous waste management initiatives include:

- Recycling tyres to make shoes, handbags, furniture, water containers rubberized asphalt concrete or for stabilization of embankments to stop erosion;

- Tyre rotation, balancing and re-treading to improve tyre life;

- Returning waste oil to the manufacturer for reprocessing, when new oil is purchased;

Corresponding author: Zoran Chachorovski, traffic and transport engineer; research fields: workshop management. E-mail: chachorovskizoran@gmail.com.
- Testing of used oil, filtration and processing in a centrifuge to prolong the life of the oil;

- Substitution of non-chlorinated brake parts cleaner for chlorinated cleaners to reduce pollution;

- Possible use of biodegradable lubricants;

- Cleaning of coolant fluids using ion exchange technology;

- Solvent distillation to allow recovery and reuse;

- Reuse of metals from oil filters at the end of their life;

- Possible substitution of batteries to reduce life cycle environmental impact;

- Recycling of batteries in regional lead smelters, after draining and neutralizing the acid;

- Disassembly of vehicles at end-of-life to allow recovery of spare parts and scrap metal recycling;

- Use of wastes which are difficult to recycle as a fuel substitute for firing bricks in kilns, in steelworks or for cement works.

\subsection{Overview of GO's Operations in South Sudan}

In 2011, a new country, The Republic of South Sudan, was created. GO has been providing support to populations affected by extreme poverty, conflict and insecurity, and periodic flooding in South Sudan. Last year, beneficiary population in South Sudan was more than 3 million and this year increased to almost 5 million. 
It is more than obvious that the fragile Government of South Sudan needed assistance of the UN Agencies and NGO's (non-governmental organizations).

In Equatoria, GO has been involved in borehole drilling, and is arranging for water quality testing, however, the results are not available as yet. GO has a fleet of over 70 trucks in South Sudan, fleet includes trucks and a mobile workshop vehicle which takes spare parts to the field for emergency repairs .

\subsection{Context of Motor Vehicle Workshops}

Activities carried out in these motor vehicle workshops include vehicle washing, changing of tyres, body repairs, regular maintenance and oil changes.

\subsection{Expected Waste Management Streams}

Hazardous waste streams from South Sudan truck maintenance workshops are expected to be essentially similar to those of every other GO motor vehicle workshop and are likely to include: tyres, batteries, waste oil, radiator coolant, brake fluid and other lubricants, refrigerants, drums, filters, paint and solvents, wastewater from cleaning vehicles and their parts and vehicles themselves, at the end of their life.

The potential environmental impact of these wastes is land contamination, air and water contamination, leading to health hazards for livestock, plants and people living and working in the area surrounding the workshops.

\subsection{Environment of South Sudan}

South Sudan's ecosystems include swamps, grasslands and tropical forests [1]. It is home to a number of national parks or protected areas including the Boma National Park, the Southern National Park and the Bandingilo National Park. These forests provide habitat for elephants, giraffes, buffalo, topi, lions, hartebeest, bongo, chimpanzee, monkeys and hogs. Bandingilo National Park hosts the world's second largest wildlife migration. A large swamp area known as the Sudd [2] located in South Sudan has been recognized since 2006 as a wetland of international importance. The Sudd is also known locally as the Bahr el Jabal [1]. It is close to Bor where GO has a workshop. The Sudd wetland, which has an area of $30,000 \mathrm{~km}^{2}$ [3], is home to crocodiles, hippopotamus, kob, reedbuck, tiang, over 400 species of birds, a rare species of hunting dog, Lycaon Pictus, and the endangered species of antelope Nile Lechwe.

South Sudan has seven distinct ecological zones: the South East Plains, the Flood Plains, the Mountain Slopes, West of the River Nile, the Iron Stone Plateau, the Central Hills Zone, and the Green Belt (parts of Equatoria) [3].

The territory of South Sudan extends over an area of approximately $640,000 \mathrm{~km}^{2}$. The climate of South Sudan is humid subtropical [4]. The main rainy season in South Sudan extends from July to October with a shorter secondary rainy season extending from March to May, but only in the extreme south of the country [5].

Temperatures in South Sudan generally range between $21.6^{\circ} \mathrm{C}$ and $36.5^{\circ} \mathrm{C}$. In Juba, the temperature range tends to be from $25^{\circ} \mathrm{C}$ to $43{ }^{\circ} \mathrm{C}$.

In theory, there are plans to move the capital of South Sudan from Juba to another town, Ramciel, some $250 \mathrm{~km}$ away [3]. However, this will not affect GO's motor vehicle workshop operations. There are approximately 64 tribes in South Sudan.

South Sudan is subject to seasonal flooding (Fig. 1) and there may still be landmines present. There is some conflict and insecurity and South Sudan and there may be a distrust of foreigners who are perceived to be benefitting at the expense of the South Sudanese.

Forest of South Sudan (Fig. 2) covers $30 \%$ of its territory, an estimated $191,667 \mathrm{~km}^{2}$. The collection of wood for fuel and charcoal production, land clearing for agriculture and the construction industry are contributing to the loss of this precious resource.

Surface water resources in South Sudan include the White Nile River and the River Yei which flows through Yei County in Equatoria state. South Sudan's 


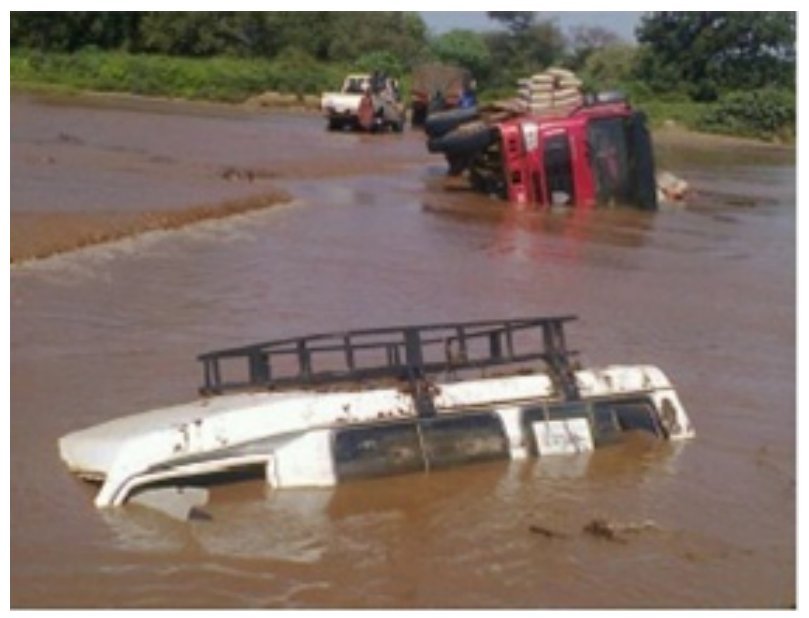

Fig. 1 The rainy season in South Sudan.

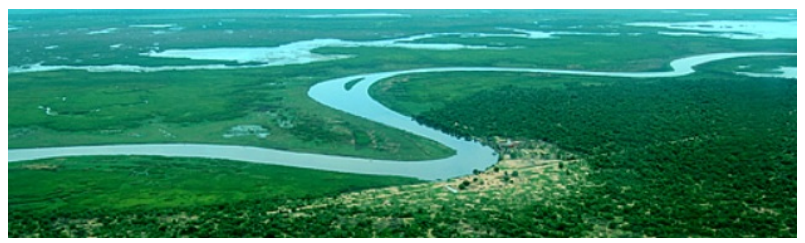

Fig. 2 Forests of South Sudan [6].

potable water resources are very fragile with some areas containing brackish groundwater, limited success with borehole sitting and drilling in some areas, and some boreholes drying up at certain times of year [5]. South Sudan's water primarily comes from underground, from drilled boreholes. The water supply from some wells and boreholes is intermittent, as the water table drops during the dry season, and in fact, many people do not have access to any potable water at all.

In addition to a wastewater treatment plant at Roton, there are potable water treatment plants in Wau and Malakal. There are three intakes for Juba's water supply [7], at Juba Teaching Hospital, near Hamza Inn and at the junction of Muniki and Gundele road where the fire brigade is located. The construction of the water supply plant is funded by JICA (Japanese International Coordination Agency) and the plant is handed over to the South Sudan Urban Water Corporation.

A 2013 study of water pollution for the Nile River passing through Juba, and streams feeding in to it, unfortunately found highly levels of contamination, mainly with faecal material [8]. Of eleven sampled boreholes, only six were found to contain potable water.

Bor and Juba, where GO has workshops, are both found on the banks of the White Nile. Both depots appear to be located fairly close to a national park. Rumbek, the site of one of GO's depots, is home to the Nile River Water Bottling Plant [9]. There have been recent reports of potable water shortages in Bor Town, Jonglei. As pressure on the water resources is high, it will be very important for GO to conserve potable water and reduce water pollution as much as possible.

\section{Methodology}

The literature review was primarily carried out using secondary sources such as internet websites in addition to the field research. At present, there is no information in the GO's documentation about managing hazardous waste in the workshops. The limitations of using the internet relate primarily to the lack of independence or scientific validity of trade or political websites, and the fact that much of the information is out of date (although it is the best available).

\section{Environmental and Hazardous Waste Management}

\subsection{Legislation Environmental Legislation}

The Republic of South Sudan has a Transitional Constitution which enshrines the right of every person and community to a clean and healthy environment (Article 4.1) [10]. The need for sustainability and the rights of future generations of South Sudanese are also enshrined in the Transitional Constitution [11]. Prior to the creation of the new country of South Sudan in 2011, there was a 2010 Environmental Bill which related to Southern Sudan [12]. The 2010 Environmental Bill aimed to promote ecosystem conservation, integrate environmental management into government plans and policies at all levels of government and contribute to the resolution of conflicts between resource exploitation and ecosystem conservation. At that time, 
the Southern Sudan Environmental Authority was created to coordinate environmental management activities being undertaken by the line ministries. South Sudan's Draft Environmental Bill (2010) dates back to the time when South Sudan was still part of Sudan and not yet an independent country. However, this old draft legislation is still the most recent available, although it has not yet been accepted by Parliament [13]. There is also a Draft South Sudan National Environment Policy (2011).

In the Draft Environment Bill, Article 60 relates to the management of hazardous waste. This article requires the relevant government agencies, together with the Ministry of the Environment, to make regulations and issue guidelines relating to hazardous waste management.

The Policy Framework for South Sudan includes the National Water Policy (2007); the Strategic Framework for Water, Sanitation and Health (2011); and the National Rural Water, Sanitation, and Hygiene Subsector Action and Investment Plan (2012-2015) [14].

For Juba City, the local government has a Juba City Sanitation Reform and Investment Plan [15].

South Sudan has a Draft National Medical Waste Management Policy [10], Draft Guidelines for the Management of Medical Waste and a Draft Medical Waste Action Plan. These documents include mention of the "polluter pays" principle, requiring those who generate waste to be responsible for ensuring its safe disposal. Waste segregation at source is mandated, as well as safe storage, transport, treatment and final disposal of medical waste.

For medium to large scale waste projects such as the construction of recycling plants, the enactment of the draft legislation would necessitate an environmental impact assessment study to obtain a permit. For simple incinerators, permits would not be required.

International legislation which needs to be considered includes the Stockholm Convention on Persistent Organic Pollutants [16] and the Basel
Convention on Trans Boundary Movements of Hazardous Wastes and Their Disposal [17]. South Sudan is also bound by the 2014 Convention on Biological Diversity, the 2014 Framework Convention on Climate Change, and the 2013 International Plant Protection Convention [18].

South Sudan had some environmental laws which were in vigor in its territory prior to the formation of the Republic of South Sudan. These include a Wildlife Conservation and National Parks Act (2003) and also a Wildlife Forces Act (2003) [19]. There is also a Timber Utilisation and Management Act (2003). The wildlife force is a disciplinary force whose role is to protect the environment in sensitive areas. Customary law, based on reconciliation, also applies in South Sudan [20]. Many of the provisions of Customary Law relate to the ownership, use and transfer of land, water, livestock and mineral resources.

In theory, the Ministry of the Environment is responsible for the preparation of legislation and guidelines, and for support to each of the state environmental protection departments. The states and counties are responsible for implementation and for carrying out inspections. Municipalities are responsible for general solid waste management but not for hazardous waste.

As part of its contribution to the United Nations Framework Convention for Climate Change Paris Agreement, South Sudan prepared a document stating its intended nationally determined contribution [21]. Though it will be some time before legislation is enacted in accordance with South Sudan's intentions, it is of great interest to GO's fleet managers and logistics staff to note that South Sudan plans to introduce emissions standards for vehicles and also plans to restrict the importation of vehicles which do not conform to allowable emissions levels.

Key draft and current Environmental Legislation include:

- Sudan's Wildlife Conservation and National Parks Act (2003) — used as a draft by the new country 
of The Republic of South Sudan;

- Sudan's Timber Utilisation and Management Act (2003) — used as a draft by the new country of The Republic of South Sudan;

- Sudan's Wildlife Forces Act (2003) —used as a draft by the new country of The Republic of South Sudan;

- Draft Environment Bill (2010) —used as a draft by the new country of The Republic of South Sudan.

\subsection{Waste Management Legislation and Its Implications}

A waste policy is expected to be developed following the adoption of the draft Environmental Protection Bill by the Government of South Sudan. There appears to be no waste management legislation existing at present. UNEP (United Nation Environmental Program) have developed Health and Safety Guidelines for Waste Pickers, however, these are not enshrined in legislation and it is therefore not mandatory for them to be followed [22].

As previously mentioned, both the Basel Convention and the Stockholm Convention should be kept in mind. In countries which are signatories to the Stockholm Convention on Persistent Organic Pollutants, any incinerators used are expected to use the best available technology to limit the levels of dioxins and furans in their air emissions to a maximum of $0.1 \mathrm{ng} \cdot 1-\mathrm{TEQ} / \mathrm{Nm}^{3}$ at $11 \% \quad \mathrm{O}_{2}$. Any wastewater treatment plants processing effluent from gas treatment scrubbers for waste incinerators must also limit their dioxin content to well below $0.1 \mathrm{ng} \cdot 1-\mathrm{TEQ}$ per litre. The wastes must also be burnt at temperatures of more than $850{ }^{\circ} \mathrm{C}$. These requirements would need to be kept in mind if there were any proposals to use hazardous waste from GO facilities for burning as fuel in cement plants or brickworks. The emissions from such plants would also need to be tested regularly.

International Legislation which applies to South Sudan includes:

- Stockholm Convention on Persistent Organic
Pollutants;

- Basel Convention;

- United Nations Framework Convention for Climate Change Paris Agreement;

- Ramsar Convention on Wetlands of International Importance.

\section{Waste Management Infrastructure}

\subsection{Government Waste Management Infrastructure}

In April 2013, UNEP commissioned a study of solid waste management in Juba "Municipal Solid Waste Composition Analysis Study, Juba, South Sudan" [23]. This report noted that municipal solid waste from Juba went to "Juba Lagoon Dump Site" which was fenced and had some assistance from Japanese agency JICA to develop management plans and introduce the use of cover materials. Some mechanical plant and equipment was available. It was noted that Juba is one of the fastest-growing cities in the world and that the solid waste management situation was concerning as at the time of the study, the Juba Lagoon Dump Site only had a projected remaining filling capacity of two years.

The Juba Lagoon Dump Site, also known as "Yei Road Landfill Site" (Fig. 3):

Waste pickers at the Yei Road site extract plastic, aluminium and other valuable materials for sale [24]. In December 2012, there were an estimated 300 such informal waste pickers collecting an estimated 6 tons of recyclables daily, from the Yei Road dumpsite's total daily waste collection of 20 tons. None of the informal

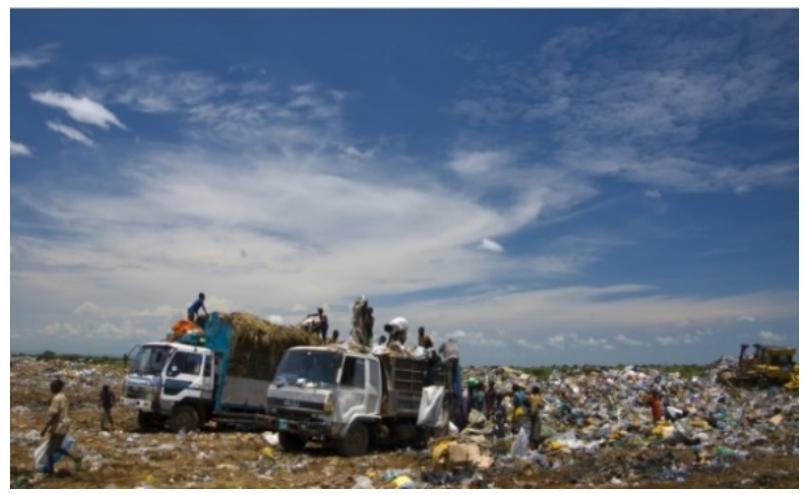

Fig. 3 Location of the Juba Lagoon Dump Site [23]. 


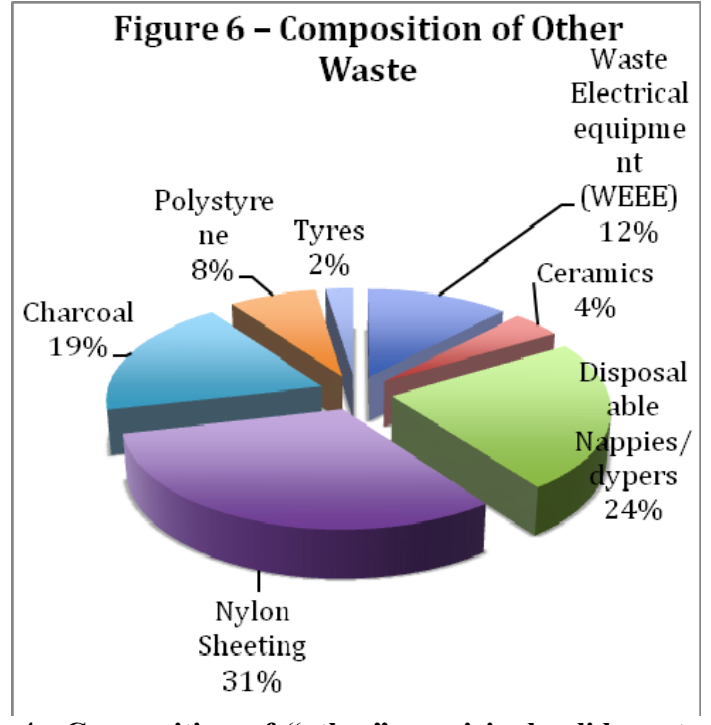

Fig. 4 Composition of "other" municipal solid waste for Juba Town [23].

waste pickers has personal protective equipment to protect them from any hazardous wastes which may be mixed together with more innocuous waste materials [23].

Aluminium recovered by waste pickers is sold to middle men who melt it down to form small bars which are exported for recycling in Uganda or Kenya. Of the "other" waste, some $12 \%$ is electronic waste, and $2 \%$ is waste tyres, as illustrated in Fig. 4:

South Sudan has a Development Plan which allows for the construction of several landfills on the outskirts of major towns [25]. There are no provisions for recycling in this development plan. The UNEP's 2010 "Keep Juba Clean and Green" campaign did not helped much to manage waste appropriately.

In 2013, The World Bank commissioned a draft Medical Waste Action Plan [10]. At the time of the preparation of this draft plan, it was noted that there was no fencing of the Yei Road site and that waste was being randomly dumped in piles without any cover materials being used. Some hazardous wastes including healthcare wastes were noted being strewn around the site. It was also noted that because the official Yei Road dumpsite is inaccessible during the wet season, an unofficial site about $5 \mathrm{~km}$ closer to the town had sprung into being.
Apart from Juba's Yei Road dumpsite, there is also a waste disposal site at Wau, where there is a trench which is inaccessible to waste disposal vehicles. In the towns of Rumbek and Yei, there are no official waste disposal sites and unfortunately waste is burnt [26].

Solid waste in Juba which is dumped rather than transported to landfills leads to the proliferation of mosquitoes which cause malaria, endemic in the region. Some plastics are burnt in Juba, and elsewhere the practice of burning plastic has been found to lead to the release of toxins such as chlorine, heavy metals, benzene, butadiene, phosgene, acetaldehyde, dioxins and furans. Breathing of these toxins has been linked to adverse health effects such as cancer.

In 2007 , it was estimated that only $15 \%$ of Juba's waste was being collected [9]. Prior to South Sudan's independence, responsibility for solid waste management in Juba was shared between the MHPIE (Ministry of Housing, Physical Infrastructure and Environment, lands and Utilities), the Equatoria State Ministry of Physical Infrastructure and the Juba Payam. In 2005, a Master Plan was prepared for solid waste management in Juba. In 2007, land was designated for the waste dumpsite on the Yei Road and an anaerobic sewage treatment pond was constructed.

At the time of writing of the World Bank's Medical Waste Management plan, expired medications were being burnt at the Yei Road dumpsite [10]. Chemical wastes in the hospital were being disposed of by pouring down the drains in health facilities, from where they would find their way into septic tanks, most of which would leak. It is noted that the off-site transportation of hazardous waste from health facilities to the Yei Road landfill does not meet international standards. A 2011 mapping of health care facilities identified 133 medical waste incinerators in existence (not necessarily functional), so there may be some skilled waste incinerator operators available in-country.

A wastewater treatment plant for sewage is available at Roton [15]. This plant does not have any capacity to 
deal with hazardous or industrial wastewater or other liquids.

Only $2 \%$ of the roads in South Sudan are paved [27], so opportunities to use waste oil or shredded tyres as an additive for asphalt can be considered to be almost non-existent in South Sudan, however, there are some plans to build a new paved road from Juba to Kapoeta and Nadapal.

Key government resources available include:

- Dumpsites at Juba and Wau;

- Roton wastewater treatment plant for sewage;

- Waste transport and compaction vehicles;

- Medical waste management incinerators-may have skilled operators;

- Plans to build new paved roads.

\subsection{Private Sector Waste Management Infrastructure}

Opportunities for recycling hazardous waste in South Sudan are likely to be very limited. At present, South Sudan recycles only four materials: scrap metal, hard plastic, aluminum and PET. For aluminium and scrap metal, two private sector operators Sandrock and Skyco purchase the waste materials at the Yei Road Landfill site and resell them to recycling companies in Uganda or Kenya. A few private individuals also sometimes buy and resell aluminium and scrap metal.

South Sudan's first national recycling planning workshop was held on December 6, 2012. Batteries, tyres and electronic waste were identified as materials which could potentially be recycled in South Sudan, however, at that time, there was no significant formal recycling taking place for these materials.

At the time of the World Bank's Medical Waste Management Study, three different major private companies were collecting municipal solid waste, as well as many small informal operators. There was one private company, "Philling Environmental" who organized a separate collection of paper, plastics and metals, with the metals being sold in Uganda for the manufacture of tools. It was noted that there was a small market for copper from electrical cables and batteries.

The two largest waste collection companies operating in South Sudan are Southern Express, with 12 trucks (many broken down in 2008), and Philling Environmental, which has many more trucks and some 300 employees.

In South Sudan, the French Embassy supports a plastic bottle recycling programme [28] and could maybe support new recycling efforts for different materials. Due to the scarcity of potable running water in Juba, there is a high consumption of bottled water (estimated at one million bottles per day). The French Embassy in South Sudan partnered with Southern Sudan Beverages Limited to implement the collection of PET bottles, to enable their subsequent recycling [29]. The South Sudanese NGO "ERP" (environmental rehabilitation programme) runs the new plastic bottle recycling operation [30]. ERP has two recycling machines and has a capacity of up to 2 tons of plastic waste daily [31].

Plastic bottles collected from institutions and residences have the caps removed, then they are ground into flakes and then exported to Uganda, China or Congo for recycling into fabrics or ropes [32]. Perhaps this experienced $\mathrm{NGO}$, ERP, may be interested in branching out into crumb rubber production and recycling in future years?

Experience gained from the plastic recycling project could be used to inform other recycling efforts, including those for hazardous waste. Safi Cleaners, a Juba waste Collection Company, participated in the South Sudan's first plastic waste recycling trial in 2008 [9]. The pilot study of plastic recycling indicated that with the prevailing economic conditions at that time, financial incentives or subsidies would be needed to introduce the plastic recycling project. Expenses incurred during the trial exceeded the revenue from the sale of the plastic by a factor of ten. The cost of labour in Juba was high and some workers expected extra payment for separating plastics from other rubbish, in spite of explanations that there would be no such 
additional payment. At that time, no export duties were paid when taking plastic for recycling across the border to Uganda.

In the absence of recycling facilities for waste oil in South Sudan, perhaps it could be used as a fuel additive for cement processing plants or industrial brickworks. East Africa Portland Cement Company has a cement warehouse in Juba but it is not known whether this company produces any cement in-country or merely imports cement from neighbouring Sudan [33]. In 2012, there were plans for a new cement processing plant to be built at Kapoeta in South Sudan [34]. The CMEC (Chinese Manufacturing and Energy Corporation) plans to build the plant [35]. It is not known whether this plant has been built as yet or when construction will be complete. This should be further investigated during a field visit.

There is a diesel-fired power station in Kapoeta [36] which may be able to use some waste from GO's motor vehicle workshops as a substitute fuel.

Although South Sudan has significant oil reserves, it has no processing capacity and relies on its northern neighbour Sudan. Casco Petroleum has a fuel storage area in Bor, Juba [37].

Kenya company "Plumbing Systems" has installed a number of small domestic and commercial jet wastewater treatment systems in Juba [37]. The small Jet brand wastewater treatment systems can be made in either plastic or concrete. This organization may be able to help with the supply, installation and maintenance of oil/water separators, which may be needed for GO's motor vehicle workshops.

$\mathrm{M}$ and $\mathrm{E}$ trading sells solar power equipment (including batteries) in South Sudan. They could perhaps be approached to determine the possibilities of reselling or giving waste batteries back to them for recycling in regional centres such as Uganda or Kenya [37].

In July 2013, Dr Andu Ezbon Adde noted in a presentation on the geology of South Sudan that there were also no geological or geophysical laboratory facilities available in South Sudan at that time [38]. This needs to be taken into account when planning equipment for environmental audits. As laboratory facilities in-country are likely to be limited, it may be necessary for GO to purchase equipment.

Key private sector resources available include:

- PET granulating plant;

- Diesel-fired power station in Kapoeta (which may perhaps use waste oil);

- Proposed cement factory for Kapoeta;

- Non-government, civil society and international organizations.

In South Sudan, as noted previously, the French government lent its financial support to the establishment of a PET recycling plant, via non-government agency AFD (Agence Francaise de Developpement). In 2013, Japanese agency JICA had some funding for working with the Ministry of the Environment to set up a Solid Waste Management Committee within the Ministry.

German government agency GTZ (German Organization for Technical Cooperation) has been involved in road construction in South Sudan [37]. If we ever wanted to use waste oil or shredded tyre waste as an additive for asphalt, they could perhaps be a useful contact. German government agencies GTZ and KFW-Development Bank have also been involved in financing improvements to South Sudan's potable water supply in the town of Juba [5]. USAID (United States Agency for International Development) has financed improvements to potable water in the towns of Wau and Malakal. A multidonor trust fund and a basic services fund channel government support towards improvements in South Sudan's water supplies.

There are a multitude of non-government agencies working in South Sudan, including BRAC, the world's largest NGO, who works on income generation projects [39].

Finally, UNEP and UNHCR (United Nations High Commissioner for Refugees) are working in South Sudan and may be interested in joint project 
implementation.

\section{Key Findings}

From the limited information available, it would appear that South Sudan uses mainly draft environmental legislation dating back to the time when the Southern part of Sudan was not yet an independent nation. It is planned for this draft legislation to be discussed and adopted by the Parliament of the Republic of South Sudan but it is not known when this occurs. There are designated waste dumping sites in the major towns such as Juba and Wau, however, these are not really properly managed engineered sanitary landfills. A wastewater treatment plant for sewage is available at place so called Roton [15]. This plant does not have any capacity to deal with hazardous or industrial waste.

Recycling opportunities in South Sudan are limited to PET [25] bottles, aluminum and small quantities of other wastes (electronic wastes, scrap metals) which are collected by informal waste pickers. Best practice management of waste oil, tyres and batteries will involve transport to neighbouring countries such as Uganda, with the permission of both governments.

In future years, South Sudan is planning to introduce legislation to control vehicle emissions, and also plans to ban the import of older vehicles which will not comply with the new emissions controls. The time frame for the introduction of this planned legislation is not yet known.

There is an environmentally-sensitive wetland of international importance in swamp area Sudd [2], fairly close to GO's Juba workshop, and it is especially important to ensure that there is no land or water contamination in this area. GO must also pay particular attention to water conservation in Bor town, where there have been recent shortages of potable water.

\section{Recommendations}

A review of the available literature on environmental legislation and recycling waste led to the following recommendations:

Used oil filters at the end of their life should be well-drained and the metals recovered by informal waste pickers at the Yei Road landfill in Juba. These could be given away rather than sold, and this would help to end hunger for the waste pickers.

As no known facilities exist for formal processing of waste oil, the petroleum company Kush Petroleum should be approached to determine whether they can accept waste oil to return to their refinery or parent company (if any). In addition, a small grant could be sought to purchase oil testing and filtration equipment to extend the life of used oil as much as possible.

Any other waste liquids (coolants, solvents), combined with waste oil which cannot be accepted by the petroleum company, should be collected and used as a supplementary fuel for the cement works in Kapoeta [5] or for industrial brickworks, provided that there are air pollution controls in place. Otherwise, unfortunately, the best options are to transport the waste to another country (e.g., Uganda) or retain it onsite until a better solution can be found.

The life of each vehicle tyre should be maximized by rotation, balancing and retreading (if possible).

Tyres should be collected in Juba and used for landscaping projects to prevent soil erosion. In the first instance, they can be used by our engineers working on road construction in hilly parts of Central Equatoria province. They could also be around GO's own compounds for landscaping, with trees planted in the middle of each tyre (to prevent mosquito breeding).

If the supply of the tyres exceeds the demand for the engineers' slope stabilisation project, then the excess tyres could be transported to nearby Ethiopia, where tyres are made into shoes for international export by the small business "Sole Rebels" [39].

Inner tubes could be recycled into a local string (“Garang”). The Waste Pickers' Association could arrange this.

Any waste paint can be donated to a local school or to the Juba town council. 
In the longer term, GO can carry out advocacy to encourage the existing PET granulating plant to branch out into crumb rubber processing from waste tyres. If we have funds for purchasing a crumb rubber machine and provide training in its use, this type of small project could help to improve food security for the women who work in the ERP recycling project and their families. Some organizations could be approached for funding, as they fund the existing PET recycling.

Juba Town Council can be approached to set an area aside for electronic waste. This will make it easier for the waste pickers to safely collect it. The area should preferably have a hard concrete or stone surface to prevent contamination of groundwater with heavy metals (however, the area should preferably be roofed drained to prevent mosquito breeding). If GO has any small grants available, we could fund this area at the Juba Yei Road dumpsite, with a view to improving food security for waste pickers while providing a safe working environment.

Substitution of solvents and lubricants with more benign alternatives (biodegradable greases, non-chlorinated brake parts cleaners) should be investigated during the site visits.

The life of vehicle batteries should be maintained as much as possible by careful storage and handling. Battery capacity should be verified using a multimeter and/or hydrometer before pronouncing that a battery has reached the end of its life.

Batteries awaiting recycling can be temporarily stored in labeled, sealed plastic drums located off the ground and covered to keep rainwater out [40]. No more than $1,000 \mathrm{~kg}$ of batteries ( 50 batteries) should be stored at any one time.

Batteries should have the acid drained before transporting to recyclers in Kenya or Uganda. During the site visit, further enquiries should be made to identify any potential local recyclers. Waste battery acid can be neutralized with baking soda or lime and should not be disposed to the sewer as it contains heavy metals.
At the end of its life, if it cannot be sold, then each vehicle should be carefully disassembled according to the manufacturer's protocols, to allow the maximum possible recovery of spare parts. Scrap metal could potentially be sold locally (to be investigated during site visit). Otherwise, this waste could also help to end hunger by supplying an income for the local waste pickers' association.

A hazardous waste management consultant plans to visit a number of truck maintenance workshops to discuss the challenges being faced, find case studies of best practice to share with other countries and help to identify any possible new recycling/reuse/repurposing and waste elimination opportunities.

\section{Conclusions}

This is necessarily a draft as the site visits and waste audits have yet to be undertaken. In the absence of many promising recycling opportunities, best practice may be simply to protect the environment during transport and disposal of waste, while minimizing workplace health and safety risks [41] for the staff involved in the maintenance of vehicles and storage of waste. It is important to minimize waste as much as possible and during the future environmental and waste assessment, possibilities for substituting solvents and lubricants with less hazardous alternatives should be investigated. A risk assessment should be carried out as part of the assessment process.

If there are no possibilities for recycling waste liquids such as oil in-country, then the main options are likely to be: (1) returned to the point of sale (only if the company has the means to then recycle the waste liquid safely); (2) indefinite storage until an alternative can be found; (3) transported to another country such as Uganda or Kenya where recycling facilities exist; or (4) combustion as a supplementary fuel for a power station, a cement factory or an industrial-scale brickworks. The fourth option should only be chosen if there are air emission controls available to ensure that the atmosphere is protected. If waste is to be transported to 
a regional centre, there may be opportunities for back loading with regional businesses which transport goods from Kampala or Nairobi, provided that only trucks which never transport food are used for this purpose. Any vehicles used for transport of hazardous materials must be designed for this purpose or must be able to transport chemicals safely.

The issue of battery disposal will be particularly difficult as the groundwater table is likely to be high in the region of GO's Bor Workshop and improper disposal of battery acid could have a potentially severe impact on groundwater resources. Fishing in the Sudd area is also an important means of earning a livelihood for the local populations [42], and fish resources could be harmed by the discharge of battery acid from Bor Workshop to stormwater. To ensure that environmental impacts are minimized, substitutes for lead-acid batteries should be investigated, and if GO is not already using gel-sealed batteries, then their introduction should be seriously considered. Existing batteries should be well-managed to ensure that they have the longest life possible.

To ensure the longest possible life before final disposal, lead-acid batteries should always be kept fully charged, and stored fully charged also [43]. Depth of discharge should also be limited as much as possible.

If waste batteries are to be stored on site for later disposal or transported to a regional centre then the acid should be drained first. Only glass or ceramic containers can be used to hold the drained acid as it will corrode metals and may dissolve some plastics also. The acid can be neutralized with baking soda (sodium bicarbonate) or otherwise washing soda/soda ash (sodium carbonate) or quicklime (calcium oxide) can be used [44]. This neutralization procedure would of course only be carried out in a well ventilated area using appropriate PPE (personal protective equipment). After neutralizing, the liquid should poured or drained in the soilsince still contains toxic heavy metals [45]. Most likely, the best option for disposal of this neutralized acid is to pour it around the base of any potted plants around the GO compound (if there are such plants). Plants such as water hyacinth (eichhornia crassipes) [46] or Indian mustard seed [47] are often used for remediation of liquids containing heavy metals [48]. Of course, any plants which have been watered with hazardous liquid wastes should not be eaten. At the end of the plant's life, it can be burnt and the ash can go to in a sealed container to a landfill site.

If GO must continue using lead-acid batteries for business reasons, then perhaps additives could be used [49] to extend the life of these lead-acid batteries. In theory, battery acid can be processed to form a harmless compound, sodium sulphate [50], which can be used in laundry detergents, textiles and glassmaking [51]. These options should be further investigated during field visits.

\section{References}

[1] Wikipedia. n.d. "South Sudan." Accessed May 12, 2017. https://en.wikipedia.org/wiki/South_Sudan.

[2] Wikipedia. n.d. "Sudd." Accessed May 12, 2017. https://en.wikipedia.org/wiki/Sudd.

[3] EPC Kenya. n.d. Study Findings Background of South Sudan. Accessed May 12, 2017. http://www.epckenya. org/images/stories/Reports/south\%20sudan $\% 20$ survey $\% 2$ Opresentation.pdf.

[4] World Bank. 2011. Sudan-Preliminary Water Information Assessment Study: Final Report. Washington, DC: World Bank. Accessed May 12, 2017. http://wwwwds.worldbank.org/external/default/WDSCon tentServer/WDSP/IB/2012/08/15/000425962_201208151 54228/Rendered/PDF/705850ESW0P1180s0Assessment 00 final0.pdf.

[5] Wikipedia. n.d. "Water Supply in South Sudan". Accessed May 12, 2017. https://en.wikipedia.org/wiki/Water_ supply_in_South_Sudan.

[6] UN Environment. n.d. "Forests of South Sudan". Accessed May 12, 2017. http://www.unep.org/disasters andconflicts/CountryOperations/southsudan/Environment alGovernance/tabid/105737/Default.aspx.

[7] Gurtong. n.d. "New Water Treatment Plant for Juba". Accessed May 12, 2017. http://www.gurtong.net/ECM/ Editorial/tabid/124/ctl/ArticleView/mid/519/articleId/388 8/New-Water-Treatment-Plant-for-Juba.aspx.

[8] Karija, M. K., Qi, S., and Lukaw, Y. S. 2013. "The 
Impact of Poor Municipal Solid Waste Management Practices and Sanitation Status on Water Quality and Public Health in Cities of the Least Developed Countries: the Case of Juba, South Sudan." International Journal of Applied Science and Technology 3 (4): 87-99. Accessed May 12, 2017. http://www.ijastnet.com/journals/ Vol_3_No_4_April_2013/11.pdf.

[9] USAID. 2009. Sudan Transitional Environment Program-Pilot Plastic Recycling Pilot Project. Final report. Accessed May 12, 2017. http://pdf.usaid.gov/pdf_docs/PNADR016.pdf.

[10] Ministry of Health of the Republic of South Sudan. 2011. Development of a Medical Waste Management Plan for South Sudan. Accessed May 12, 2017. http://wwwwds.worldbank.org/external/default/WDSCon tentServer/WDSP/IB/2013/02/04/000333037_201302041 30911/Rendered/PDF/E41280EA0P132101300SS0MW0 Final0Rep.pdf.

[11] Government of Sothern Sudan. 2011. The Transitional Constitution of the Republic of South Sudan. Accessed May 12, 2017. http://www.necsouthsudan.org/sites/ default/files/resources/Transitional $\% 20$ Constitution $\% 20$ o f\%20The \%20Republic \%20of $\% 20$ South $\% 20$ Sudan $\% 2 \mathrm{C} \%$ 202011.pdf.

[12] William Kosar. n.d. Environmental Law in Southern Sudan. Accessed May 12, 2017. http://www.williamkosar. com/index.php/library/presentations/11-south-sudans-env ironmental-protection-bill/file.

[13] UN Environment. n.d. UNEP Environmental Governance South Sudan. Accessed May 12, 2017. http://www.unep.org/disastersandconflicts/CountryOperat ions/southsudan/EnvironmentalGovernance/tabid/105737 /Default.aspx.

[14] USAID. 2013. USAID South Sudan Draft Water, Sanitation and Hygiene (WASH) Program. Accessed May 12, 2017. https://www.usaid.gov/sites/default/files/docu ments/1860/USAID\%20South\%20Sudan\%20Draft\%20W ater $\% 2 \mathrm{C} \% 20$ Sanitation $\% 20$ and $\% 20$ Hygiene $\% 20$ Program $\% 202013-2018$.pdf.

[15] USAID. 2015. Assessment of Roton Wastewater Lagoon in Juba. Accessed May 12, 2017. http://pdf.usaid.gov/pdf_docs/PA00KNS1.pdf.

[16] POPs. n.d. Stockholm Convention on Persistent Organic Pollutants. Accessed May 12, 2017. http://www.pops.int/ documents/convtext/convtext_en.pdf.

[17] Peiry, K. K. 2010. Basel Convention on Transboundary Shipments of Hazardous Wastes and Their Disposal. UN. Accessed May 12, 2017. http://legal.un.org/avl/pdf/ha/bcctmhwd/bcctmhwd_e.pdf.

[18] WIPO. n.d. South Sudan IP Legal Texts. Accessed May 12, 2017. http://www.wipo.int/wipolex/en/profile.jsp? code $=$ SS.
[19] Gurtong. n.d. Laws of South Sudan. Accessed May 12, 2017. http://www.gurtong.net/Governance/Constitution Laws/LawsofSouthSudan/tabid/342/Default.aspx.

[20] Gurtong. n.d. Customary Law. Accessed May 12, 2017. http://www.gurtong.net/Governance/ConstitutionLaws/C ustomaryLawsofSouthSudan/tabid/343/Default.aspx.

[21] Republic of South Sudan. n.d. Intended Nationally Determined Contribution (Draft). Accessed May 12, 2017. http://www4.unfccc.int/submissions/INDC/Published $\% 20$ Documents/South\%20Sudan/1/South\%20Sudan\%20Inten ded $\% 20$ Nationally $\% 20$ Determined $\% 20 \% 20 \% 20 \% 20$ Con tribution.pdf.

[22] UNEP. 2013. Health and Safety Guidelines for Waste Pickers in South Sudan. Accessed May 12, 2017. http://postconflict.unep.ch/publications/UNEP_South_Su dan_Health\&Safety_Waste_Pickers.pdf.

[23] UNEP. 2013. Municipal Solid Waste Composition Analysis Study-Juba, South Sudan. Accessed May 12, 2017. http://postconflict.unep.ch/publications/UNEP South_Sudan_Juba_Waste_composition_2013.pdf.

[24] Africa Review. n.d. Waste Pickers at the Yei Road. Accessed May 12, 2017. http://www.africareview.com/ Special-Reports/The-Juba-poor-find-a-livelihood-in-the-c hocking-plastic-trash/-/979182/3099904/-/b9an2c/-/index. html.

[25] ENEP, UK AID, and ERP. 2012. 1st National Planning Workshop on Recycling "Challenges and Opportunities". Workshop report. Accessed May 12, 2017. http://static1.squarespace.com/static/51a49c00e4b093105 c278f58/t/51cc11f7e4b080d01936ba66/1372328439758/ RSW_Report.pdf.

[26] AWEPA. n.d. No Time to Waste-Sustainable Environmental Management in a Changing Southern Sudan. Accessed May 12, 2017. http://www.awepa.org/ wp-content/uploads/2013/06/No-Time-To-Waste-Sustain able-Environmental-Management-in-a-Changing-Souther n-Sudan.pdf.

[27] African Development Bank Group. 2012. Interim Country Strategy Paper 2012-2014. Accessed May 13, 2017. http://www.afdb.org/fileadmin/uploads/afdb/Docu ments/Project-and-Operations/2012-2014\%20-\%20South $\% 20$ Sudan $\% 20-\% 20$ Interim $\% 20$ Country $\% 20$ Strategy $\% 2$ OPaper.pdf.

[28] ERP. n.d. Environnemental Réhabilitation Program-Juba Recycles. Accessed May 13, 2017. http://erp-southsudan.org/juba-recycles-1.

[29] ERP. n.d. Juba Recycles Environmental Rehabilitation Program. Accessed May 13, 2017. http://erp-southsudan.org/recycling.

[30] Red Pepper. n.d. South Sudan Gets First Plastic Recycling Program. Accessed May 13, 2017. http://www.redpepper.co.ug/south-sudan-gets-first-plastic 
-recycling-program/.

[31] Africa Review. n.d. Juba's Poor Find a Living in the Chocking Plastic Trash. Accessed May 13, 2017. http://www.africareview.com/Special-Reports/The-Jubapoor-find-a-livelihood-in-the-chocking-plastic-trash/-/979 182/3099904/-/b9an2c/-/index.html.

[32] VOA News. n.d. With a Little Help, South Sudan Women Turn Trash into Money. Accessed May 13, 2017. http://www.voanews.com/content/south-sudan-women-re cycling-plastic/1911408.html.

[33] CEMNET. n.d. Cement Processing-Sudan. Accessed May 13, 2017. http://www.cemnet.com/content/ gcr/intros/187.pdf.

[34] Gurtong. n.d. Chinese Company to Explore Cement Investment in Kapoeta. Accessed May 13, 2017. http://www.gurtong.net/ECM/Editorial/tabid/124/ctl/Arti cleView/mid/519/articleId/6521/Chinese-Company-To-E xplore-Cement-Investment-In-Kapoeta.aspx.

[35] Gurtong. n.d. Cement Plant to be Established in Kapoeta County. Accessed May 13, 2017. http://www.gurtong. net/ECM/Editorial/tabid/124/ctl/ArticleView/mid/519/arti cleId/7058/Cement-Plant-to-be-Established-in-Kapoeta-C ounty.aspx.

[36] Allafrica. n.d. USAID Inaugurates Power Plant in Kapoeta, Eastern Equatoria. Accessed May 13, 2017. http://allafrica.com/stories/201102050021.html.

[37] Plumbing System Ltd. n.d. Kenya Plumbing Systems Recycling in Regional Centres Such as Uganda or Kenya. Accessed May 13, 2017. http://www.plumbingsystems.co. ke/our-work.

[38] Slide Share. n.d. Geology and Mineral Investment Opportunities in South Sudan. Accessed May 13, 2017. http://www.slideshare.net/miningontop/mota-2013-southsudan-presentation.

[39] Kiva. n.d. BRAC South Sudan. Accessed May 13, 2017. https://www.kiva.org/partners/107.

[40] Environment and Natural Resources. n.d. Guideline for the Management of Waste Batteries. Accessed May 14, 2017. http://www.enr.gov.nt.ca/sites/default/files/guide lines/batteryguideline.pdf.

[41] Health and Safety Executive. 2013. Example Risk Assessment for a Motor Vehicle Mechanical Repair Workshop. Accessed May 14, 2017. http://www.hse.gov. uk/risk/casestudies/pdf/mvr.pdf.

[42] USAID. n.d. Environmental Impact Assessment of the Bor Counties' Dyke Rehabilitation Project, South Sudan: Integrated Assessment Report. Accessed May 15, 2017. http://pdf.usaid.gov/pdf_docs/pnaea465.pdf.

[43] Battery University. n.d. Can the Lead-Acid Battery
Compete in Modern Times?. Accessed May 15, 2017. $\mathrm{http} / / /$ batteryuniversity.com/learn/article/can_the_lead_ac id_battery_compete_in_modern_times.

[44] Schneider Electric. n.d. Material Safety Data Sheet-Battery Pack Containing Lead Acid Battery. Accessed May 15, 2017. http://www2.schneiderelectric. com/resources/sites/SCHNEIDER_ELECTRIC/content/li ve/FAQS/158000/FA158828/en_US/APC_MSDS_Austra lia.pdf.

[45] Stack Exchange. n.d. What Should I do With Leftover Sulfuric Acid. Accessed May 15, 2017. http://diy.stackexchange.com/questions/13780/what-shou ld-i-do-with-leftover-sulfuric-acid-from-a-sump-pump-ba ttery-backup.

[46] Odjegba, V. J., and Fasidi, I. O. 2007. "Phytoremediation of Heavy Metals by Eichhornia Crassipes." The Environmental List 27 (3): 349-55. Accessed May 15, 2017. http://rd.springer.com/article/10.1007/s10669-0079047-2.

[47] Pamila, D., Kumar, M. D., Sivalingam, A., and Thirumarimurugan, M. $2016 . \quad$ "Green Revolution-Removal of Lead from Battery Industrial Effluent by Phytoremediation Using Eichhornia Crassipes." International Journal for Scientific Research and Development 4 (11): 451-3. Accessed May 15, 2017. https://www.scribd.com/doc/298833760/Green-Revolutio n-Removal-of-Lead-from-Battery-Industrial-Effluent-byPhytoremediation-using-Eichhornia-Crassipes.

[48] University of South Florida. n.d. Phytoremediation of Copper in Water Using Indian Mustard Grass. Accessed May 15, 2017. http://fcit.usf.edu/florida/teacher/science/ $\bmod 1 /$ phytoremediation.html.

[49] Turquoise Energy Ltd. n.d. The Lead Acid Battery Longevity Additive. Accessed May 15, 2017. http://www.saers.com/recorder/craig/TurquoiseEnergy/N a2SO4.html.

[50] Rao, S. R. 2006. Resource Recovery and Recycling from Metallurgical Wastes. Amsterdam: Elsevier Science. Accessed May 15, 2017. https://books.google.it/books?id $=0 \mathrm{mJuMpFZPAC} \& \mathrm{pg}=\mathrm{PA} 202 \& \mathrm{lpg}=\mathrm{PA} 202 \& \mathrm{dq}=$ how + to + convert+sulfuric + battery + acid + to + sodium + sulfate $\&$ sou rce=bl\&ots=wgg5A62mp3\&sig=0jjEfKXK5Z6EsRp_3LJ nj8DHLY\&hl=en\&sa $=$ X\&ved $=0$ ahUKEwiU1 NaUxurLA $\mathrm{hXG1}$ ywKHYZhDSQ4ChDoAQgnMAI\# $\mathrm{v}=$ onepage $\& \mathrm{q}=$ how $\% 20$ to $\% 20$ convert $\% 20$ sulfuric $\% 20$ battery $\% 20$ acid $\%$ 20 to $\% 20$ sodium $\% 20$ sulfate $\& \mathrm{f}=$ false.

[51] Battery Solution. n.d. "How Battery Are Recycled?." Accessed May 15, 2017. http://www.batteryrecycling. com/Battery+Recycling+Process. 